\title{
GAME ADVERTISING VS TV ADVERTISING WHICH ONE IS MORE EFFECTIVE IN BUILDING BRANDS?
}

\author{
Albertus Edward Goutama \\ Fakultas Ekonomi Dan Bisnis Universitas Ma Chung, Malang \\ 111410006@student.machung.ac.id
}

\begin{abstract}
There are a many pros and cons regarding which are more effective between TV Advertising and Games Advertising in being a medium of promotion media. As we know TV Advertising and Games Advertising is widely used big companies in promoting a product as well as embed Brand Image and Brand in Mind Set society in general. This article shows a number of pentung points that make TV Advertising is superior to a number of advantages it has, Compared Games Advertising in promoting a product.
\end{abstract}

Keywords: brand, brand image, advertising, games advertising, tv advertising.

\section{Pendahuluan}

Situasi pasar yang semakin global membuat persaingan bisnis di Indonesia semakin ketat. Situasi seperti ini mengharuskan perusahaan agar dapat bertahan di dunia persaingan bisnis. Salah satu cara agar perusahaan dapat bertahan adalah menarik minat konsumen untuk membeli produk.

Dalam pengenalan dan pengembangan sebuah produk dibutuhkan sarana promosi, yang salah satunya adalah iklan, dengan iklan konsumen atau pembeli potensial dapat mengetahui keberadaan dan keunggulan produk yang diproduksi oleh produsen. Yang setelah fase ini diharapkan konsumen atau pembeli potensial dapat menggunakan produk, mengetahui kualitas produk, dan citra merek dari produk, sehingga menimbulkan kepuasan dan melakukan pembelian berulang atau membentuk loyalitas terhadap produk

Minat konsumen dapat diraih dengan memberikan informasi yang menarik kepada konsumen mengenai produk yang dijual. Memberikan informasi ini dikenal sebagai kegiatan promosi. Promosi memerlukan sebuah strategi. Strategi promosi tidak hanya bertujuan sebagai pemberian informasi produk kepada konsumen, tetapi menjadi senjata bagi perusahaan untuk memengaruhi konsumen agar membeli suatu produk.

Fread dan Mangun (1999:128) promosi adalah semua yang dilakukan untuk membantu penjualan suatu produk atau jasa di tiap tempat jaringan penjualan, mulai dari bahan-bahan presentasi yang di gunakan seorang tenaga penjual ketika melalui penawaran hingga siaran niaga, televisi, atau iklan di surat kabar yang mencoba memikat pelanggan agar memperoleh kesan yang menyenangkan terhadap apa yang di iklankan. Jadi periklanan adalah bentuk komunikasi dengan tujuan tertentu untuk mempengaruhi pikiran dan tindakan audiens sasaran.

Keberhasilan perusahaan dalam mempengaruhi konsumen untuk keputusan pembelian sangat didukung oleh upaya membangun komunikasi pada konsumen dan membangun merek yang kuat melalui strategi pemasaran, selanjutnya melakukan inovasi 
untuk menghasilkan varian baru pada produk perusahaan, agar mencapai keunggulan jangka waktu yang panjang.

Perusahaan memasarkan suatu produk/jasa tidak hanya memperhatikan kualitas, harga kompetitif, dan ketersediaan produk bagi konsumen sasaran, tetapi juga memerlukan komunikasi yang berkesinambungan dengan para konsumen potensial, sehingga tercipta hubungan yang erat antara konsumen dan produsen. Salah satu bentuk komunikasi yang dapat dilaksanakan adalah iklan. Jika dilaksanakan dengan baik akan membuat konsumen mengetahui produk yang dipasarkan oleh perusahaan, dengan harapan mereka tertarik dan mengambil keputusan untuk membeli produk perusahaan. Jika terjadi kesalahan dalam melakukan iklan, maka akan berdampak pada citra perusahaan dan mengakibatkan konsumen beralih pada produk lain. Sejalan dengan pertumbuhan ekonomi, aktivitas dunia usaha di Indonesia mengalami peningkatan. Hal ini secara tidak langsung mempengaruhi perkembangan usaha dibidang periklanan. Periklanan kini telah mendapatkan pengakuan luas sebagai salah satu ujung tombak dalam aktivitas pemasaran, dan dipercaya sebagai ujung pendongkrak penjualan.

Iklan juga sudah meramaikan hampir seluruh media, baik media cetak maupun elektronik. Iklan merupakan sarana komunikasi yang dilakukan oleh perusahaan untuk memasarkan produknya. Iklan dilakukan dengan tujuan untuk membujuk, memberitahu, mempengaruhi dan menarik minat beli dari konsumen. Pemilihan media yang tepat dapat berpengaruh terhadap efektivitas komunikasi yang disampaikan. Efektivitas iklan sangat penting bagi perencanaan periklanan dan promosi. Efektivitas dari periklanan dapat dilakukan dengan mengukur efek komunikasi yang disampaikan, melalui iklan yang tujuannya untuk mengetahui potensi pengaruh iklan tersebut pada kesadaran, pengetahuan atau preferensi dari konsumen.

Televisi merupakan salah satu media massa yang cukup diminati oleh para advertiser (pengiklan) karena salah satu keunggulan media massa televisi adalah menciptakan daya rangsang yang kuat pada khalayak dibandingkan jenis media massa lainnya. Dengan memasang iklan di media massa televisi juga dapat memvisualisasikan atau mendemontrasikan produk atau jasa yang di perjual belikan. Industri televisi swasta juga tak bisa lepas dari keberadaan para advertiser (pengiklan) ini karena untuk menghidupi industri yang begitu besar ini tentunya memerlukan biaya yang tidak sedikit sehingga membutuhkan keuntungan yang cukup besar. Sedangkan satu-satunya penghasilan dari industri televisi swasta adalah dari para advertiser (pengiklan). Sehingga keberadaan kedua pihak ini merupakan simbiosis mutualisme (saling menguntungkan).

Pada awalnya periklanan di televisi hanya mengandalkan penjualan TVC (TV Commercials) atau spot di commercial break (jeda iklan di setiap program). Adapun spot yang dijual bisa berdurasi 60's, 30's, 15's dan 10's. Hal ini dianggap efektif oleh para advertiser (pengiklan) karena pada saat itu stasiun televisi di Indonesia masih terbatas serta teknologi yang ada masih belum berkembang dengan pesat seperti yang terjadi pada saat ini. Dengan adanya keterbatasan tersebut, maka khalayak tidak dapat menghindari munculnya iklan pada acara yang diselenggarakan oleh stasiun televisi dan khalayak yang dijangkau lebih luas.

Smartphone (Telepon Cerdas) adalah telepon genggam yang mempunyai kemampuan tingkat tinggi, kadang-kadang dengan fungsi yang menyerupai komputer. Belum ada standar pabrik yang menentukan arti telepon cerdas. Bagi beberapa orang, telepon pintar merupakan telepon yang bekerja menggunakan seluruh perangkat lunak sistem operasi yang menyediakan hubungan standar dan mendasar bagi pengembang 
aplikasi. Bagi yang lainnya, telepon cerdas hanyalah merupakan sebuah telepon yang menyajikan fitur canggih seperti surel (surat elektronik), internet dan kemampuan membaca buku elektronik (e-book) atau terdapat papan ketik (baik sebagaimana jadi maupun dihubung keluar) dan penyambung VGA.

Dengan kata lain, telepon cerdas merupakan komputer kecil yang mempunyai kemampuan sebuah telepon. Dari kemempuan yang dimiliki oleh smartphone membuatnya sangat diminati orang diseluruh dunia, dikarenakan dengan hanya membawa smartphone banyak hal yang akan bisa dilakukan diluar melakukan panggilan dan SMS (Short Message Service). Android adalah salah satu dari banyak sistem oprasi yang ada dan sistem oprasi yang paling diminati oleh konsumen, hal ini dikarenakan harga dari smartphone yang mengsusung sistem ini lebih murah dibandingkan iOS dan MAC OS sebagai pesaing yang eksklusif di usung oleh iPhone.

Advertising (periklanan) adalah bentuk komunikasi yang kompleks yang beroperasi untuk mengejar tujuan dan menggunakan strategi untuk mempengaruhi pikiran, perasaan, dan tindakan konsumen.

Para advertiser (pengiklan) tidak sembarangan untuk melakukan placement iklan di semua stasiun televisi melainkan terlebih dahulu melihat rating dan share dari setiap acara yang diadakan oleh setiap stasiun televisi. Kotler dan Armstrong (2008:117) periklanan adalah semua bentuk terbayar presentasi nonpribadi dan promosi ide, barang atau jasa dengan sponsor tertentu.

Adapun pengertian dari rating adalah presentasi dari orang yang menonton suatu program terhadap seluruh populasi televisi (TV). Yang dimaksud dengan populasi TV di sini adalah semua orang yang berusia lima tahun ke atas yang mempunyai akses terhadap televisi di rumah tangganya masing-masing. Sedangkan share hanya menghitung orang yang saat itu sedang berada di depan TV karena selama 24 jam tidak mungkin semua populasi menonton TV bersama-sama. Bertahun-tahun rating dan share dihitung oleh sebuah perusahaan bernama Nielsen dan menjadi barometer atau tolak ukur dari keberhasilan suatu acara di stasiun televisi. Kedua hal tersebutlah yang menjadi patokan survei oleh para advertiser (pengiklan) dengan dibantu oleh agency iklan.

Tak mengherankan apabila terdapat sebuah acara yang memiliki rating dan share yang tinggi maka jeda iklan yang diberikan akan semakin lama untuk mendapatkan keuntungan yang lebih banyak.

Advergame, atau yang biasa disebut in-game advertising tidak secara langsung mempromosikan brand di sepanjang alur permainan. Seperti halnya pada contoh game Pro Evolution Soccer atau Winning Eleven, dari contoh game tersebut maka akan ditemukan berbagai macam logo brand di banner sepanjang pinggir lapangan bola. Logo brand tersebut adalah in-game advertisement. Definisi umumnya, in-game advertisement adalah iklan penempatan produk di suatu game. Penempatan logo produk atau game tersebut tidak hanya terdapat di banner pinggir lapangan sepak bola, tapi juga muncul pada loading screen game atau pada item tertentu yang diperoleh oleh karakter pemain di tengah alur permainan.

John von Neumann dan Oskar Morgenstern (1953:144) menjelaskan bahwa permainan terdiri atas sekumpulan peraturan yang membangun situasi bersaing dari dua sampai beberapa orang atau kelompok dengan memilih strategi yang dibangun untuk memaksimalkan kemenangan sendiri atau pun untuk meminimalkan kemenangan lawan. 
Artikel ini bertujuan untuk membandingkan tingkat efektifitas antara Iklan TV (TV Advertising) dan Iklan Game (Game Advertising) dalam mempromosikan suatu produk serta menanamkan Citra Merek dan Brand di Mind Set masyarakat secara umum.

\section{Kajian Teori}

\subsection{Iklan (Adsvertising)}

Periklanan merupakan pesan-pesan penjualan yang paling persuasive yang diarahkan kepada calon pembeli yang paling potensial atas produk barang atau jasa tertentu dengan biaya yang semurah-murahnya. Sedangkan iklan adalah promosi barang, jasa, perusahaan, dan ide yang harus dibayar oleh sponsor. Sponsor dalam hal ini merupakan perusahaan tertentu yang nantinya menjadi klien penyedia jasa promosi.

Kotler and Amstrong (2002:153) iklan adalah bagian dari bauran promosi (Promotion Mix) dan bauran promosi adalah bagian dari bauran pemasaran (Marketing Mix). Secara sederhana iklan didefinisikan sebagai pesan yang menawarkan suatu produk yang ditujukan kepada masyarakat lewat suatu media. Sedangkan periklanan (Advertising) adalah segala biaya yang harus dikeluarkan sponsor untuk melakukan presentasi dan promosi nonpribadi dalam bentuk gagasan, barang atau jasa.

Efektifitas iklan adalah kondisi sejauh mana efek pesan iklan yang disampaikan itu dapat menarik perhatian, dimengerti, dipahami, membangkitkan emosi dan menggerakkan sasarannya untuk memberikan tanggapan yang dikehendaki. Iklan yang efektif bekerja pada dua tingkatan, yaitu yang pertama mereka harus memuaskan tujuan konsumen dengan menciptakan ikatan dengan mereka dan menyampaikan pesan yang relevan. Sedangkan yang kedua, iklan harus mencapai tujuan dari pemasang iklan.

Sebagai penyampaian pesan, iklan umumnya ditempatkan pada tempat-tempat dimana peminat dapat dengan mudah atau sering mengaksesnya baik dalam bentuk visual gambar atau suara. Iklan memiliki dua jenis utama yaitu

1. Periklanan Institusi (institutional advertising)

Didesain untuk meningkatkan citra sebuah perusahaan daripada mempromosikan suatu produk tertentu.

2. Periklanan Produk

Digunakan untuk mempromosikan manfaat suatu produk maupun jasa tertentu. Tahap produk ini dalam siklus hidupnya sering kali menentukan jenis iklan produk yang digunakan, antara lain :

a. Periklanan Perintisan (pioneering advertising)

b. Periklanan Bersaing (competitive advertising)

c. Periklanan Perbandingan (comparative advertising)

Secara umum, periklanan dihargai karena dikelan sebagai pelaksana beragam fungsi komunikasi yang penting bagi perusahaan bisnis dan organisasi lainnya.

1. Informing

Iklan yang membuat konsumen sadar (aware) akan merek-merek baru, mendidik mereka tentang berbagai fitur dan manfaat merek, serta memfasilitasi penciptaan merek yang positif.

2. Persuading

Iklan yang efektif akan mampu mempersuasi (membujuk) pelanggan untuk mencoba produk dan jasa yang diiklankan. 


\section{Reminding}

Iklan menjaga agar merek perusahaan tetap segar dalam ingatan konsumen.

4. Adding Value

Terdapat tiga cara mendasar dimana perusahaan bisa member nilai tambah bagi penawaran-penawaran mereka : inovasi, penyempurnaan kualitas, atau mengubah persepsi konsumen.

Media yang digunakan dalam Iklan, yaitu:

1. Media Cetak merupakan media yang memuat pesan bertopik tunggal dan satu pemikiran secara bersamaan. Beberapa jenis media cetak antara lain :

i. Koran / Surat Kabar

ii. Majalah

2. Media Elektronik

i. Radio

ii. Televisi

3. Media interaktif meliputi internet, CD-ROM, alam maya (virtual reality), dan nomor-nomor telepon bebas pulsa yang interaktif.

4. Media Alternatif meliputi periklanan melalui yellow pages, periklanan melalui video, penayangan produk di bioskop, dan rambu-rambu.

\subsection{Iklan TV (TV Advertising)}

Media televisi pada hakekatnya merupakan suatu sistem komunikasi yang menggunakan suatu rangkaian gambar elektronik yang dipancarkan secara cepat, berurutan, dan diiringi unsur audio. Iklan televisi adalah sebuah film persuasif yang sangat pendek, ditayangkan kepada audiens pada menit-menit celah antar program, atau pada saat program sengaja dihentikan untuk menayangkan iklan.

Sebagai media yang paling potensial untuk menyampaikan pesan iklan, televisi memiliki tiga kekuatan yaitu efisiensi biaya, dapat memberikan dampak yang kuat, dan dapat memberikan pengaruh yang kuat. Namun, di sisi lain iklan televisi juga memiliki beberapa keterbatasan antara lain, biaya yang dikeluarkan untuk memproduksi dan menyiarkan iklan televisi sangat besar, khalayak atau audiens iklan televisi tidak selektif, dan televisi tidak luwes dalam pengaturan teknis

Di sisi lain iklan televisi adalah sebuah media untuk menjual barang atau jasa bukan menghibur dengan alasan bahwa sebuah iklan hanya melaporkan suatu barang atau jasa dan tidak ada hubungannya antara rasa suka kepada iklan-iklan yang ditayangkan.

Bungin (2011:107) Pengertian iklan televisi adalah sebuah dunia magis yang dapat mengubah komoditas ke dalam gemerlapan yang memikat dan memesona menjadi sebuah sistem yang keluar dari imajinasi dan muncul kedalam dunia nyata melalui media.

Televisi digunakan sebagai media periklanan karena bekerja sebagai film. Media televisi menceritakan kisah, membangkitkan emosi, menciptakan fantasi, dan dapat memberi dampak visual yang kuat.

Pesan yang baik akan dirancang oleh personel komunikasi dengan memutuskan apa yang harus dikatakan (isi pesan), dan cara mengatakannya (struktur dan format pesan), termasuk iklan televisi. 


\subsection{Iklan Game (Games Advertising)}

Advertising games (Advergames) adalah jenis game yang secara eksplisit maupun secara menyeluruh memasukkan muatan promosi sebagai marketing tools ke dalam sebuah game. Pada advergame, brand menyatu dengan cerita, misi maupun aktifitas lain dalam game. Penerapan advergames ini dapat terlihat pada beberapa unsur games seperti karakter dengan brand tertentu, gameplay menampilkan ciri khas produk tertentu, banner iklan pada suatu segmen game, ataupun unsur lainnya.

Pada dasarnya, advergames telah ada sejak dulu, namun terus berubah dan berkembang dari masa ke masa. Advergames bukan hanya berupa video games saja, akan tetapi bentuk permainan tradisional semacam monopoli, ular tangga, maupun catur, dapat menjadi suatu advergames dengan catatan adanya brand awareness yang terdapat di dalamnya. Advergames berkembang ke media digital mengikuti perkembangan teknologi, bahkan kini media smartphone pun telah disisipi beberapa aplikasi advergames.

Advergames dapat dikategorikan menjadi dua jenis, yaitu :

1. In-Advertising Games, ini adalah jenis game yang menyisipkan unsur-unsur produk maupun brand perusahaan ke dalam game yang dibangun. Dengan kata lain, game jenis ini tidak seluruhnya menampilkan content produk yang bersangkutan.

2. Pure Advertising Games, untuk jenis game kedua ini adalah, seluruh gameplay, judul, maupun unsur yang terdapat dalam game tersebut seluruhnya murni merupakan brand awareness dari produk yang bersangkutan. Contoh game PepsiMan yang secara jelas mengangkat brand Pepsi meski dalam gameplay-nya tidak selalu harus berkesesuaian.

Tujuan dari Games Advertising dapat diklasifikasikan menjadi 2 yaitu

\section{Product Placement}

Dalam product placement, brand yang muncul di dalam game sebagai produk yang dapat digunakan oleh suatu karakter di dalam game. Sebagai contoh brand mobil yang dikendarai di dalam game atau brand minuman yang diminum di dalam game. Product placement ini akan sesuai untuk game yang memiliki kesesuaian tema dengan campaign brand tersebut dan produknya cocok untuk dimasukkan ke dalam game-nya.

\section{Visually Adapted Content/Rebranded games}

Dalam hal ini brand mengadaptasi game yang sudah ada, kemudian memperbarui game tersebut sebagai game yang bertujuan mempromosikan merek, istilah lainnya adalah Rebrand. Ini bisa menjadi alternatif untuk merek yang ingin membuat advergame, tetapi menginginkan biaya pengembangan yang lebih rendah dan diadaptasi dari game yang sudah terbukti populer. 


\section{Pembahasan}

Implikasi Manajemen Pemasaran dalam bidang pemasaran menggunakan TV Advertising diperlukan beberapa kriteria agar tercapai hasil yang sesuai ataupun maksimal dalam melakukan promosi produk melalui iklan TV Advertising.

Pada iklan TV (TV Advertising) isi pesan pemasar harus menentukan daya tarik atau tema yang akan menghasilkan respon yang diinginkan kepada pemirsa, dan struktur pesan juga harus memperhatikaan kesimpulan, menghadirkan argumen yang kuat tentang brand yang akan di tampilkan.

Format Pesan juga menjadi bagian penting, karena format yang kuat untuk pesan berpengaruh pada bagaimana pemirsa menerima Brand yang kita tampilkan di iklan TV, format pesan tersebut melingkup semua elemen seperti kata-kata, bunyi dan suara beserta bahasa tubuh.

Implikasi pemasaran melalui sisi Games Advertising membutuhkan sejumlah pemahaman mengenai kesesuaian tema dengan produk yang akan dipromosikan, terdapat beberapa studi kasus yang mengungkapkan bahwa Games Advertising tanpa memandang kesesuaian tema dengan games yang ada justru menimbulkan Spamming sehingga tujuan untuk memasarkan produk menjadi kurang efektif atau bahkan tidak efektif.

Dari hasil kajian tentang iklan games yang telah diuraikan pada bagian sebelumnya maka pemasar perlu memperhatikan penempatan produk, kesesuaian iklan merek pada iklan di games / AdverGames, dikarenakan In-Advertising Games merupakan yang paling efektif dengan menyisipkan unsur-unsur produk maupun brand perusahaan ke dalam game yang dibangun namun kesesuaian penempatan produk sangat berpengaruh secara signifikan dalam menanamkan Brand dalam Games yang ada.

Berdasarkan hasil pembahasan diatas, maka dapat terlihat kekuatan dari Media Televisi dibanding Games Advertising, antar lain

a. Efisiensi Biaya

Banyak pengiklan memandang televisi sebagai media yang paling efektif untuk menyampaikan pesan-pesan komersialnya dibandingkan Games Advertising. Dikarenakan salah satu keunggulan $T V$ Advertising adalah kemampuan menjangkau khalayak sasaran yang sangat luas yang tidak terjangkau oleh media lainnya termasuk Games Advertising. Jangkauan masal ini menimbulkan efisiensi biaya untuk menjangkau setiap kepala.

b. Dampak yang kuat

Kemampuannya $T V$ Advertising menimbulkan dampak yang kuat terhadap konsumen, dengan tekanan pada sekaligus dua indera: penglihatan dan pendengaran. Televisi juga mampu menciptakan kelenturan bagi pekerjaanpekerjaan kreatif dengan mengkombinasikan gerakan, kecantikan, suara, warna, drama, dan humor.

c. Pengaruh yang kuat

Kebanyakan masyarakat meluangkan waktunya dimuka Televisi sebagai sumber berita, hiburan dan sarana pendidikan dibandingkan memainkan sebuah Games. Kebanyakan calon pembeli lebih percaya pada perusahaan yang mengiklankan produknya di televisi daripada yang ditampilkan pada iklan di Games. 


\section{Simpulan}

Berdasarkan hasil diatas maka dapat disimpulkan bahwa salah satu media di Indonesia yang masih menjadi media yang paling efektif adalah Televisi, dikarenakan jangkauan dan efiesensi biayanya, Games Advertising memang akurat namun tidak setiap orang di Indonesia maupun di dunia memainkan sejumlah Games tersebut. Oleh karena itu media yang utama masih dikuasai oleh televisi.

\section{DAFTAR PUSTAKA}

Afdjani, H. 2010. Makna Iklan Televisi (Studi Fenomenologi Pemirsa di Jakarta Terhadap Iklan Televisi Minuman "Kuku Bima Energi” versi Kolam Susu). Jurnal Ilmu Komunikasi.

Ajisaksono, Y \& Wiratmojo, B. 2013. Efektivitas Produk Placement dalam Game Online (Studi Deskriptif Kuantitatif Efektivitas Product Placement Specs "buktikan Indonesiamu" pada Game Online Footballsaga 2 Berdasarkan EPIC Model oleh Member Forum di forum.footballsaga.com). Jurnal Administrasi Bisnis (JAB).

Andri, G, Dewi, N \& Yonaldi, S. 2012. Penggaruh Iklan, Citra Merek dan Kepuasan Konsumen terhadap Loyalitas Konsumen dalam Menggunakan Vaseline Hand And Body Lotion di Kota Padang (Studi Kasus di PT. Unilever Cabang Padang). Jurnal Manajemen dan Kewirausahaan.

Febriana. 2015. Pengaruh Iklan Televisi Terhadap Kesadaran Merek Serta Dampaknya pada Keputusan Pembelian. Jurnal Administrasi Bisnis (JAB).

Fitriyah, N. 2013. Iklan Televisi dan Perilaku Konsumtif Anak-Anak (Studi Kasus Pada Siswa SDN 13 Serang). Jurnal AL-AZHAR INDONESIA SERI PRANATA SOSIAL.

Ghirvu, A. 2012. In Game Advertising : Advantages and Limitiations for Advertisers. The USV Annals of Economics and Public Administration.

Kriestian, A \& Gultom, T, M. 2016. Pengaruh Penempatan Produk dan Kesesuaian Iklan pada Minat Beli yang Dimoderasi Sikap Merek di AdverGames. Jurnal Managemen dan Bisnis.

Purwaningwulan, M. 2013. "Sihir" Iklan Televisi dalam Menstimuli Perilaku Konsumtif Anak-Anak. Jurnal Ilmu Politik dan Komunikasi.

Qolbi, Fauzi, A \& Sunarti. 2014. Pengaruh Iklan Terhadap Sikap Konsumen (Survei pada Pengunjung yang Pernah Bermain Game Pro Evolution Soccer di Flux Capital Of Entertainment Kecamatan Blimbing Kota Malang). Jurnal Administrasi Bisnis (JAB). 
Williams, K, Petrosky, A, Hernandez, E \& Page, R. 2010. Product placement effectiveness: revisited and renewed. Journal of Management and Marketing Research. 